\title{
Biosynthesis of laccase by Aspergillus flavus NG85 Isolated from Saint Catherine protectorate
}

\author{
M.I. A. Ali, S. A. Ouf, N.M. Khalil" and M. N. Abd El-Ghany \\ Department of Botany and Microbiology, Faculty of Science, \\ Cairo University, Giza 12613, Egypt.
}

\begin{abstract}
THE MICROFLORAL pictures of Saint Catherine protectorate, Giza Zoo Garden and Cairo University soil were studied. The obtained 31 microbial isolates were qualitatively and quantitatively screened for laccase production. Aspergillus flavus from Saint Catherine protectorate achieved highest laccase production on both solid and liquid media. Identification of this fungal species was further confirmed at the molecular level based on nuclear ribosomal DNA internal transcribed spacer (ITS) identities and was found to be $A$. flavus strain NG85. The fungus produced statistically highest amounts of laccase after 10 days of growth at $36.7^{\circ} \mathrm{C}$ and when growth medium was adjusted at $\mathrm{pH} 5$. D-glucose at a concentration of $24 \mathrm{~g} / \mathrm{l}$ was the best carbon source. The leading nitrogen source was peptone used at $2.51 \mathrm{~g} / 1$. Supplementation of copper sulfate at concentration $10 \mu \mathrm{M}$ to the optimized growth medium caused an increase of $122 \%$ in enzyme yield. The crude laccase preparation of A. flavus NG85 from Saint Catherine protectorate showed antiproliferative activity against colon carcinoma cells (HCT-116) andbreast carcinoma cells (MCF-7) with $\mathrm{IC}_{50}$ values of 24.3 and $41.3 \mu \mathrm{g} / \mathrm{ml}$, respectively, and a less inhibitory effect against hepatocellular carcinoma cells (HepG-2).
\end{abstract}

Keywords: Laccase, Aspergillus flavus NG85, Biosynthesis, Optimization, Cytotoxic activity.

Laccase (benzenediol oxygen oxidoreductase, EC 1.10.3.2) is a highly unspecific enzyme containing up to 4 copper atoms within their catalytic sites (Duran and Esposito, 2000).It catalyses the oxidation of various phenolic compounds and aromatic amines with molecular oxygen as an electron acceptor (Palmeri et al., 1993).

Laccase production has been described in fungi, plants and bacteria (Mayer and Staples, 2002). Yoshida first described laccase in 1883 from the exudates of the Japanese lacquer tree, Rhusvernicifera. However in 1896, for the first time, both Bertrand and Laborde demonstrated laccase to be a fungal enzyme (Levine, 1965 and Thurston, 1994). Laccase production occurs in various fungi over a wide range of taxa. Fungi from the deuteromycetes, ascomycetes (Aisemberg et al., 1989) as well as basidiomycetes (Sadhasivam et al., 2008) are the known producers of laccase. Some soil bacteria were also reported to produce extracellular laccase (Martins et al., 2002).

*E-mail: neveen@ @sci.cu.edu.eg tel.: +201003643976 
In fungi, laccases play a variety of physiological roles including morphogenesis, fungal plant pathogen/host interaction, stress defense, and lignin degradation (Giardina et al., 2010).

Due to its relatively broad substrate specificity, it has wide potential industrial applicability, including pulp bleaching in the paper industry, dye decolorization, oxygen cathode development for biofuel cells, biosensors, bioremediation, and detoxification of environmental pollutants.Heap et al. (2014) used laccase in an enzymatic pretreatment method to improve lignocellulosic saccharification Laccases have also applications in the medical side to prepare certain drugs like anticancer drugs and they are added in cosmetics to minimize their toxic effects (Couto and Herrera, 2006).

In view of the importance of laccases, the present study aimed at investigating laccase production by some microorganisms isolated from different habitats. More consideration was given to optimize cultural conditions for maximum laccase production by the most potent microorganism. Furthermore, the antitumor activity of the crude laccase extract was tested against some cancer cell lines.

\section{Material and Methods}

Microfloral picture of collected soil samples

For isolation of fungi and bacteria, soil samples were collected from different habitats; Saint Catherine protectorate (South Sinai), Cairo Zoo Garden (Giza), and Cairo University (Giza).The microfloral picture of each soil sample was investigated. Fungal isolation was carried out according to Johnson et al. (1960) using soil dilution plate method. Czapek-Dox agar medium was used for isolation of fungi which contained (g/l): sucrose, 20; $\mathrm{NaNO}_{3}, 2 ; \mathrm{K}_{2} \mathrm{HPO}_{4}, 1 ; \mathrm{KCl}, 0.5$; $\mathrm{MgSO}_{4} .7 \mathrm{H}_{2} \mathrm{O}, 0.5 ; \mathrm{FeSO}_{4} .7 \mathrm{H}_{2} \mathrm{O}, 0.01$ and agar, 15. Streptomycin $(30 \mu \mathrm{g} / \mathrm{ml})$ was added to the above medium after sterilization and cooling.

Bacterial isolation was carried out using nutrient agar medium which contained (g/l): Peptone, 5; Beef extract, 3; Nacl, 5; Agar, 15. The final $\mathrm{pH}$ was adjusted to 6.8 at $25^{\circ} \mathrm{C}$. The medium was then sterilized by autoclaving at $121^{\circ} \mathrm{C}$ and 1.5 bars for $15 \mathrm{~min}$.

The developing colonies were counted (colonies/g dry soil). The relative density of each microorganism (R.D. \%) was calculated as percentage of the total microorganisms count.

The isolated fungal colonies were identified up to the species level according to the morphological characters and microscopic examination. This was made through the help of Gilman (1957),Moubasher (1993), Raper and Fennell (1965) and Watanabe (2002). Species diversity $(\mathrm{H})$ was determined according to Pielou (1966).

Egypt. J. Bot., 55, No. 1 (2015) 
Qualitative screening for laccase production by isolated microorganisms

The basal medium (Olga et al., 1998), containing chromogenic substrate as indicator, was used for screening microorganisms for laccase production. It contained (g/l): Peptone, 3.0; Glucose, 10.0; $\mathrm{KH}_{2} \mathrm{PO}_{4}, 0.6 ; \mathrm{ZnSO}_{4}, 0.001$; $\mathrm{K}_{2} \mathrm{HPO}_{4}, 0.4 ; \mathrm{FeSO}_{4}, 0.0005 ; \mathrm{MnSO}_{4}, 0.05 ; \mathrm{MgSO}_{4}, 0.5 ;$ Agar ,20.0; Dist. $\mathrm{H}_{2} \mathrm{O}$ up to $1000 \mathrm{ml}$. Guaiacol $0.1 \%(\mathrm{w} / \mathrm{v})$ was added to the above medium (Kiiskinenand Saloheimo, 2004).

Each microorganism was inoculated onto these plates. Positive results were indicated bycolor production from chromogenic substrate metabolism after incubation at $30^{\circ} \mathrm{C}$ for 3 or 7 days in case of bacteria or fungi, respectively.

Quantitative estimation of laccaseproduction by isolated microorganisms

Triplicate flasks containing $50 \mathrm{ml}$ of the previous sterilized medium were inoculated with $1 \mathrm{~cm}$ diameter fungal discs taken from the periphery of 7-day old cultures grown on the Czapek-Dox agar plates or bacterial discs taken from 2-day old cultures grown on nutrient agar plates. The flasks were incubated at $30^{\circ} \mathrm{C}$ for 3 or 10 days for bacteria or fungi, respectively. The culture filtrate was used for measuring the extracellular laccase production.

Laccase activity was assayed with guaiacol as substrate. The reaction mixture contained $3.9 \mathrm{ml}$ acetate buffer $(10 \mathrm{mmol} / \mathrm{l}, \mathrm{pH} 5.0), 1 \mathrm{ml}$ guaiacol $(2 \mathrm{mmol} / \mathrm{L})$ and $0.1 \mathrm{ml}$ properly diluted enzyme solution and was incubated at $35{ }^{\circ} \mathrm{C}$ for 30 min. Absorbance was read at $470 \mathrm{~nm}$. In the blank, guaiacol was replaced with acetate buffer (Das et al., 2008).

Laccase activity unit is expressed in $\mu$ mol of substrate oxidized per milliliter per minute, in the following equation: $\mathrm{U} \mathrm{ml}^{-1} \mathrm{~min}^{-1}=\Delta \mathrm{Abs}\left(10^{6}\right)(\varepsilon \mathrm{RT})^{-1}$, where $\triangle \mathrm{Abs}$ is the difference between final and initial absorbances, $\varepsilon$ is the extinction coefficient of laccase product $\left(\varepsilon \max =6,740 \mathrm{Mol}^{-1} \mathrm{~cm}^{-1}\right)$, $\mathrm{R}$ is the volume in milliliters of supernatant, and $\mathrm{T}$ is the reaction time in minutes.

Molecular identification of Aspergillus flavus from Saint Catherine protectorate

Identification of Aspergillus flavus from Saint Catherine protectorate was further confirmed usingnuclear ribosomal DNA internal transcribed spacer (ITS) sequencing. Genomic DNA was isolated using Qiagen kit. Internal transcribed spacer (ITS) region of 5.8S rRNA was amplified using the primers ITS1 and ITS2. Sequencing of PCR amplified product was performed at Macrogen (South Korea). The resulting sequence was entered into the BLAST algorithm of National Centre of Biological Information (NCBI) database to obtain closely related phylogenetic sequences. A phylogenetic tree was constructed using MEGA 6 software. The obtained sequence was then submitted to the GenBank of NCBI database. 
Effect of some cultural conditions on extracellular laccase production by Aspergillus flavus

Eight factors were investigated to study their effects on laccase production by A. flavus. Those factors were, incubation periods at 2, 4, 6, 8, 10, 12 or 14 days; incubation temperature at $5,15,25,35,40,50,60$ or $70^{\circ} \mathrm{C}$; $\mathrm{pHs}$ at $2,3,4,5,6,7$ or 8; carbon source: glucose, sucrose, lactose, fructose, starch or maltose; glucose concentrations at $0.1,5,10,15,20,25,30$ or $40 \mathrm{~g} / \mathrm{l}$; nitrogen source: $\mathrm{NaNO}_{3}$ $(2 \mathrm{~g} / \mathrm{l}), \quad \mathrm{NH}_{4} \mathrm{NO}_{3}(1.9 \mathrm{~g} / \mathrm{l}), \quad \mathrm{KNO}_{3}(2.4 \mathrm{~g} / \mathrm{l}), \mathrm{NH}_{4} \mathrm{Cl}(2 \mathrm{~g} / \mathrm{l}),\left(\mathrm{NH}_{4}\right)_{2} \mathrm{SO}_{4}(2.1 \mathrm{~g} / \mathrm{l})$, glycine $(1.8 \mathrm{~g} / \mathrm{l})$, or peptone $(2.64 \mathrm{~g} / \mathrm{l})$; peptone concentrations at $0.5,1,2,3,4$ or $5 \mathrm{~g} / \mathrm{l}$ and metal ions $(10 \mu \mathrm{M})$ asFeSO ${ }_{4} \cdot 7 \mathrm{H}_{2} \mathrm{O}, \mathrm{CaCl}_{2} .2 \mathrm{H}_{2} \mathrm{O}, \mathrm{MgSO}_{4} \cdot 7 \mathrm{H}_{2} \mathrm{O}$, $\mathrm{MnSO}_{4} \cdot \mathrm{H}_{2} \mathrm{O}, \mathrm{NaCl}, \mathrm{KCl}$ or $\mathrm{CuSO}_{4} \cdot 5 \mathrm{H}_{2} \mathrm{O}$. Triplicate flasks containing the optimized Czapek-Dox's medium were prepared. The medium was inoculated with fungal discs and incubated under the previous successive conditions.

\section{Evaluation of Cytotoxic Effects of crude protein extract}

The crude protein extract from A.flavus NG85filtrate was partially purified. Cold ethanol was slowly added with stirring to the fungal extract until reachedthe concentration of $80 \%(\mathrm{v} / \mathrm{v})$. After standing for $1 \mathrm{hr}$, the protein precipitate was removed by centrifugation at $10,000 \mathrm{rpm}$ for $15 \mathrm{~min}$. at $4^{\circ} \mathrm{C}$.

The cytotoxic activity of protein extract was tested against colon carcinoma cells (HCT-116 cell line), breast carcinoma cells (MCF-7 cell line) or hepatocellular carcinoma cells (HepG-2 cell line). These cell lines were obtained from the American Type Culture Collection (ATCC). The cells were propagated in Dulbecco's modified Eagle's medium (DMEM) supplemented with 10\% heatinactivated fetal bovine serum, $1 \%$ L-glutamine, HEPES buffer and $50 \mu \mathrm{g} / \mathrm{ml}$ gentamycin. All cells were maintained at $37^{\circ} \mathrm{C}$ in a humidified atmosphere with $5 \% \mathrm{CO}_{2}$ and were subcultured two times a week.

For cytotoxicity assay (Wilson, 2000), eacht ested cell line was seeded in 96well plate at a cell concentration of $1 \times 10^{4}$ cells per well in $100 \mu 1$ of growth medium. Fresh medium containing different concentrations of enzymic protein extract was added after $24 \mathrm{hr}$ of seeding. Two-fold serial dilutions of protein extract were added to confluent cell monolayer dispensed into 96-well, flatbottomed microtiter plates (Falcon, NJ, USA) using a multichannel pipette. The microtiter plates were incubated at $37^{\circ} \mathrm{C}$ in a humidified incubator with $5 \% \mathrm{CO}_{2}$ for a period of $48 \mathrm{hr}$. Three wells were used for each concentration of protein extract. Control cells were incubated without protein extract. After the end of incubation period, the viable cells yield was determined by a colorimetric method. In brief, the media were aspirated and the crystal violet solution (1\%) was added to each well for at least $30 \mathrm{~min}$. The plates were rinsed using tap water to remove excess stain. Glacial acetic acid (30\%) was then added to all wells and mixed thoroughly, and then the absorbance of the plates were measured after gently shaken on microplate reader (TECAN, Inc.), using a test wavelength of $590 \mathrm{~nm}$. The absorbance is proportional to the number of surviving cells in the culture plate. All the results were corrected for background absorbance detected

Egypt. J. Bot., 55, No. 1 (2015) 
in wells without adding stain. Treated samples were compared with the control cells. All experiments were carried out in triplicate. The cell cytotoxic effect of each tested compound was calculated (Mosmann, 1983).

The percentage of cell viability in relation to control was calculated. The $50 \%$ cell cytotoxic concentration $\left(\mathrm{IC}_{50}\right)$, the concentration required to kill or cause visible changes in 50\% of intact mammalian cells, was estimated from graphic plots. STATA statistical analysis package was used for the dose response curve drawing in order to calculate $\mathrm{IC}_{50}$.

\section{Statistical analysis}

Data presented in each experiment were means of triplicate assays. The SPSS 16.0 software was used in determination of standard error (SE), the least significant difference (LSD) and for regression analysis.

\section{Results}

Microfloral picture

In case of soil of Saint Catherine protectorate (SCP), it appears that 5 fungal isolates were isolated using Dox's medium with species diversity $(\mathrm{H})=0.4$ (Table 1). A total of 952.5 colonies/g dry soil from Saint Catherine protectorate were isolated. Genus Aspergillus was dominant and constituted $50.0 \%$ of the total count. It was represented by Aspergillus flavus (R.D. 28.6\%) followed by A. fumigatus (R.D. 17.1\%). Alternaria alternata was the third in rank of density (21.4 \% R.D. of the total count). Penicillium chrysogenumand Rhizopusstolonifer accounted for $17.9 \%$ and $10.7 \%$ of the total fungal count, respectively.One bacterial isolate from the soil of SCP was encountered on nutrient agar medium (Table 2).

For the soil of Giza Zoo Garden (GZG), Genus Aspergillus was also dominant on Dox's medium and constituted $63.7 \%$ of the total count (Table 1). It was represented by A.fumigatus (R.D. $28.0 \%$ ) followed by A. niger (R.D. $15.5 \%$ ), A.terreus (R.D. 7.8\%,) A.versicolor and A. flavus (R.D. 6.2\%, each).Two bacterial isolates were isolated on nutrient agar medium from this soil (Table 2).

Similarly, Genus Aspergillus was dominant in Cairo University soil (CUS) constituting $67.2 \%$ of the total count on Dox's medium (Table 1). It was represented by 5 species. A.niger was the highest in count (R.D. $19.7 \%$ ), followed by A.flavus (R.D. 16.7\%). Aspergillus terreus, A.fumigatus and A.aculeatus came next with relative densities of 13.6, 10.6 and $7.6 \%$, respectively. Three bacterial isolates (no. 4, 5 and 6) were medium (Table 2). 
TABLE 1. Total count (colony/g dry soil), relative density percentage (R.D \%)and species diversity $(\mathbf{H})$ of fungal isolates from Saint Catherine Protectorate (SCP), Giza Zoo Garden (GZG) and Cairo University Soil (CUS).

\begin{tabular}{|l|l|l|l|l|l|l|}
\hline \multirow{2}{*}{ Fungal isolate } & \multicolumn{2}{|c|}{ SCP } & \multicolumn{2}{c|}{ GZG } & \multicolumn{2}{c|}{ CUS } \\
\cline { 2 - 7 } & $\begin{array}{l}\text { Total } \\
\text { count }\end{array}$ & $\begin{array}{l}\text { R.D. } \\
\mathbf{\%}\end{array}$ & $\begin{array}{l}\text { Total } \\
\text { count }\end{array}$ & $\begin{array}{l}\text { R.D. } \\
\text { \% }\end{array}$ & $\begin{array}{l}\text { Total } \\
\text { count }\end{array}$ & $\begin{array}{l}\text { R.D. } \\
\%\end{array}$ \\
\hline Aspergillus species & & & & & & \\
\hline A. aculeatus & N.D. & N.D. & N.D. & N.D. & 175.4 & 7.6 \\
\hline A. flavus & 272.1 & 28.6 & 143.4 & 6.2 & 386.0 & 16.7 \\
\hline A. fumigatus & 204.1 & 21.4 & 645.2 & 28.0 & 245.6 & 10.6 \\
\hline A. niger & N.D. & N.D. & 358.4 & 15.5 & 456.1 & 19.7 \\
\hline A. terreus & N.D. & N.D. & 179.2 & 7.8 & 315.8 & 13.6 \\
\hline A. versicolor & N.D. & N.D. & 143.4 & 6.2 & N.D. & N.D. \\
\hline Other species & & & & & & \\
\hline Alternaria alternate & 204.1 & 21.4 & 251.0 & 10.8 & 140.4 & 6.1 \\
\hline Cladosporium sphaerospermum & N.D. & N.D. & 215.1 & 9.3 & N.D. & N.D. \\
\hline Emericella nidulans & N.D. & N.D. & 10.8 & 0.5 & N.D. & N.D. \\
\hline Fusarium oxisporum & N.D. & N.D. & 71.7 & 3.1 & 105.3 & 4.5 \\
\hline Penicillium chrysogenum & 170.1 & 17.9 & 215.1 & 9.3 & 210.5 & 9.1 \\
\hline Rhizopusstolonifer & 102.1 & 10.7 & 71.7 & 3.1 & 280.7 & 12.1 \\
\hline Total & $\mathbf{9 5 2 . 5}$ & & $\mathbf{2 3 0 4 . 9}$ & & $\mathbf{2 3 1 5 . 8}$ & \\
\hline Number of species & $\mathbf{5}$ & & $\mathbf{1 1}$ & & $\mathbf{9}$ & \\
\hline Species diversity (H) & $\mathbf{0 . 4}$ & & $\mathbf{0 . 6}$ & & $\mathbf{0 . 6}$ & \\
\hline R.D. & & & & & \\
\hline
\end{tabular}

R.D. $\%=$ Relative density as percentage of total species count.N.D. = not detected .

TABLE 2. Total count (colony/g dry soil) and relative density percentage (R.D \%) of bacterialisolates from Saint Catherine Protectorate (SCP), Giza Zoo Garden (GZG) and Cairo University Soil (CUS).

\begin{tabular}{|l|l|l|l|l|l|l|}
\hline \multirow{2}{*}{ Bacterial isolate } & \multicolumn{2}{|l|}{ SCP } & \multicolumn{2}{l|}{ GZG } & \multicolumn{2}{c|}{ CUS } \\
\cline { 2 - 8 } & $\begin{array}{l}\text { Total } \\
\text { count }\end{array}$ & $\begin{array}{l}\text { R.D. } \\
\mathbf{\%}\end{array}$ & $\begin{array}{l}\text { Total } \\
\text { count }\end{array}$ & $\begin{array}{l}\text { R.D. } \\
\text { \% }\end{array}$ & $\begin{array}{l}\text { Total } \\
\text { count }\end{array}$ & $\begin{array}{l}\text { R.D. } \\
\%\end{array}$ \\
\hline Isolate (1) & 238.1 & 100 & N.D. & N.D. & N.D. & N.D. \\
\hline Isolate (2) & N.D. & N.D. & 143.4 & 30.8 & N.D. & N.D. \\
\hline Isolate (3) & N.D. & N.D. & 322.6 & 69.2 & N.D. & N.D. \\
\hline Isolate (4) & N.D. & N.D. & N.D. & N.D. & 350.9 & 50.0 \\
\hline Isolate (5) & N.D. & N.D. & N.D. & N.D. & 315.8 & 45.0 \\
\hline Isolate (6) & N.D. & N.D. & N.D. & N.D. & 35.1 & 5.0 \\
\hline Total & $\mathbf{2 3 8 . 1}$ & & $\mathbf{4 6 6}$ & & $\mathbf{7 0 1 . 8}$ & \\
\hline
\end{tabular}

R.D. \% = Relative density as percentage of total isolate count.N.D. = not detected .

Egypt. J. Bot., 55, No. 1 (2015) 
Qualitative screening and quantitative assay of laccase production by 31 microbial isolates

Table 3. reveals qualitative screening (diameter of colored zone, $\mathrm{mm}$ ) and quantitative assay $(\mathrm{U} / \mathrm{ml})$ for laccase production by microbial isolates from the three isolation habitats. It appears that Aspergillus flavusfrom Saint Catherine protectorate was highly distinctive in laccase production $(15.2 \mathrm{~mm})$. It was followed by A. flavus from Giza Zoo garden (12.0 mm). A bacterial isolate (no. 3) from Giza Zoo garden came third $(6.00 \mathrm{~mm})$ along with $A$. fumigatus from Cairo University soil $(5.50 \mathrm{~mm})$.Concerning quantitative estimation of the enzyme, Aspergillus flavus from SCP produced the highest significant amounts of laccase $(59.50 \mathrm{U} / \mathrm{ml})$. The A. flavus isolate from GZG came next $(31.01 \mathrm{U} / \mathrm{ml})$ then followed by $A$. flavus from CUS (18.99 U/ml).

By the end of the screening part of the work, Aspergillus flavus from SCP proved to be the most potent laccase producer on both solid and liquid media. Its identification was further confirmed at the molecular level.

\section{Molecular identification of Aspergillus flavus}

DNA was isolated from Aspergillus flavus from SCP and the ITS region of 5.8S rRNA was amplified using the specific primers ITS1 and ITS2. The sequence was determined using automated sequencers. Amplification and sequencing of fungal rRNA gene resulted in $545 \mathrm{bp}$-long nucleotide sequence. NCBI Blast search sequence similarity was conducted against the existing nonredundant nucleotide sequence database. This showed maximum identity (100\%) with A. flavus species. The phylogenetic tree was constructed (Fig. 1) to show sequence alignment with available sequences from NCBI data bank (first 15 hits in Blast results). The 545bp-long nucleotide sequence was deposited in NCBI Gen Bank and was given a strain identifier, A. flavus NG85, with accession number: KJ855143.

\section{Effect of some cultural conditions on laccase production by A. flavus NG85 Incubation period}

The effect of incubation period on laccase production by A. flavus NG85 growth is shown in Fig. 2. The gradual increase in time led to concomitant increase in the amount of laccase. Optimum incubation period was found to be 10 days where $41 \mathrm{U} / \mathrm{ml}$ were assayed. More increase in incubation period above optimum led to decrease in enzyme activity. 
TABLE 3. Qualitative and quantitative screening for laccase production by microorganisms isolated from Saint Catherine protectorate (SCP), Giza Zoo Garden (GZG) and Cairo University Soil (CUS) .

\begin{tabular}{|c|c|c|}
\hline Microorganism & Colored zone (mm) & Laccase activity (U/ml) \\
\hline \multicolumn{3}{|l|}{ SCP } \\
\hline Alternaria alternata & $2.00 \mathrm{~g}$ & $10.43 \mathrm{j}$ \\
\hline Aspergillus flavus & $15.2 \mathrm{a}$ & 59.50 a \\
\hline Aspergillus fumigatus & $2.50 \mathrm{f}$ & $3.41 \quad 0$ \\
\hline Rhizopus stolonifer & $0.00 \quad \mathrm{i}$ & $0.15 \quad \mathrm{w}$ \\
\hline Penicillium chrysogenum & $0.00 \quad \mathrm{i}$ & $0.46 \mathrm{uv}$ \\
\hline Bacteria (1) & $0.00 \quad \mathrm{i}$ & $3.12 \mathrm{p}$ \\
\hline \multicolumn{3}{|l|}{ GZG } \\
\hline Alternaria alternata & $1.00 \mathrm{~h}$ & $5.05 \mathrm{n}$ \\
\hline Aspergillus aculeatus & $0.00 \quad \mathrm{i}$ & $31.01 \mathrm{~b}$ \\
\hline Aspergillus flavus & $12.0 \mathrm{~b}$ & $17.95 \mathrm{~d}$ \\
\hline Aspergillus fumigatus & $3.45 \mathrm{~d}$ & 6.821 \\
\hline Aspergillus niger & $0.00 \quad \mathrm{i}$ & $15.13 \mathrm{~h}$ \\
\hline Aspergillus versicolor & $3.20 \quad \mathrm{e}$ & $16.62 \mathrm{e}$ \\
\hline Aspergillus terreus & $0.00 \quad \mathrm{i}$ & $6.08 \mathrm{~m}$ \\
\hline Emericella nidulans & $2.00 \mathrm{~g}$ & $12.02 \mathrm{i}$ \\
\hline Fusarium oxisporum & $3.50 \mathrm{~d}$ & 0.74 stu \\
\hline Penicillium chrysogenum & $0.00 \quad \mathrm{i}$ & $1.93 \mathrm{r}$ \\
\hline Rhizopus stolonifer & $0.00 \quad \mathrm{i}$ & $12.17 \mathrm{i}$ \\
\hline Bacteria (2) & $0.00 \quad \mathrm{i}$ & $15.43 \mathrm{~g}$ \\
\hline Bacteria (3) & $6.00 \quad \mathrm{c}$ & $7.33 \mathrm{k}$ \\
\hline \multicolumn{3}{|l|}{ CUS } \\
\hline Aspergillus aculeatus & $0.00 \quad \mathrm{i}$ & $0.45 \quad \mathrm{~V}$ \\
\hline Aspergillus flavus & $3.50 \mathrm{de}$ & $18.99 \mathrm{c}$ \\
\hline Aspergillus fumigatus & $5.50 \mathrm{c}$ & $16.02 \mathrm{f}$ \\
\hline Aspergillus niger & $0.00 \quad \mathrm{i}$ & $0.89 \mathrm{~s}$ \\
\hline Alternaria alternata & $2.00 \mathrm{fg}$ & $12.02 \mathrm{i}$ \\
\hline Rhizopus stolonifer & $0.00 \quad \mathrm{i}$ & $0.74 \mathrm{st}$ \\
\hline Fusarium oxisporum & $2.5 \mathrm{f}$ & $15.58 \mathrm{~g}$ \\
\hline Penicillium chrysogenum & $0.00 \mathrm{i}$ & 0.45 tuv \\
\hline Aspergillus terreus & $1.50 \mathrm{gh}$ & $14.99 \mathrm{~h}$ \\
\hline Bacteria (4) & $1.00 \mathrm{~h}$ & $0.30 \mathrm{vW}$ \\
\hline Bacteria (5) & $0.00 \mathrm{i}$ & $2.23 \mathrm{q}$ \\
\hline Bacteria (6) & $0.00 \quad \mathrm{i}$ & $3.12 \mathrm{p}$ \\
\hline LSD (at 0.01) & 0.34 & 0.24 \\
\hline
\end{tabular}

The least significant difference (LSD) was calculated at $99 \%$ confidence interval (probability of error $p=0.01$ ). Means followed by the same letters are statistically nonsignificant.

Egypt. J. Bot., 55, No. 1 (2015) 


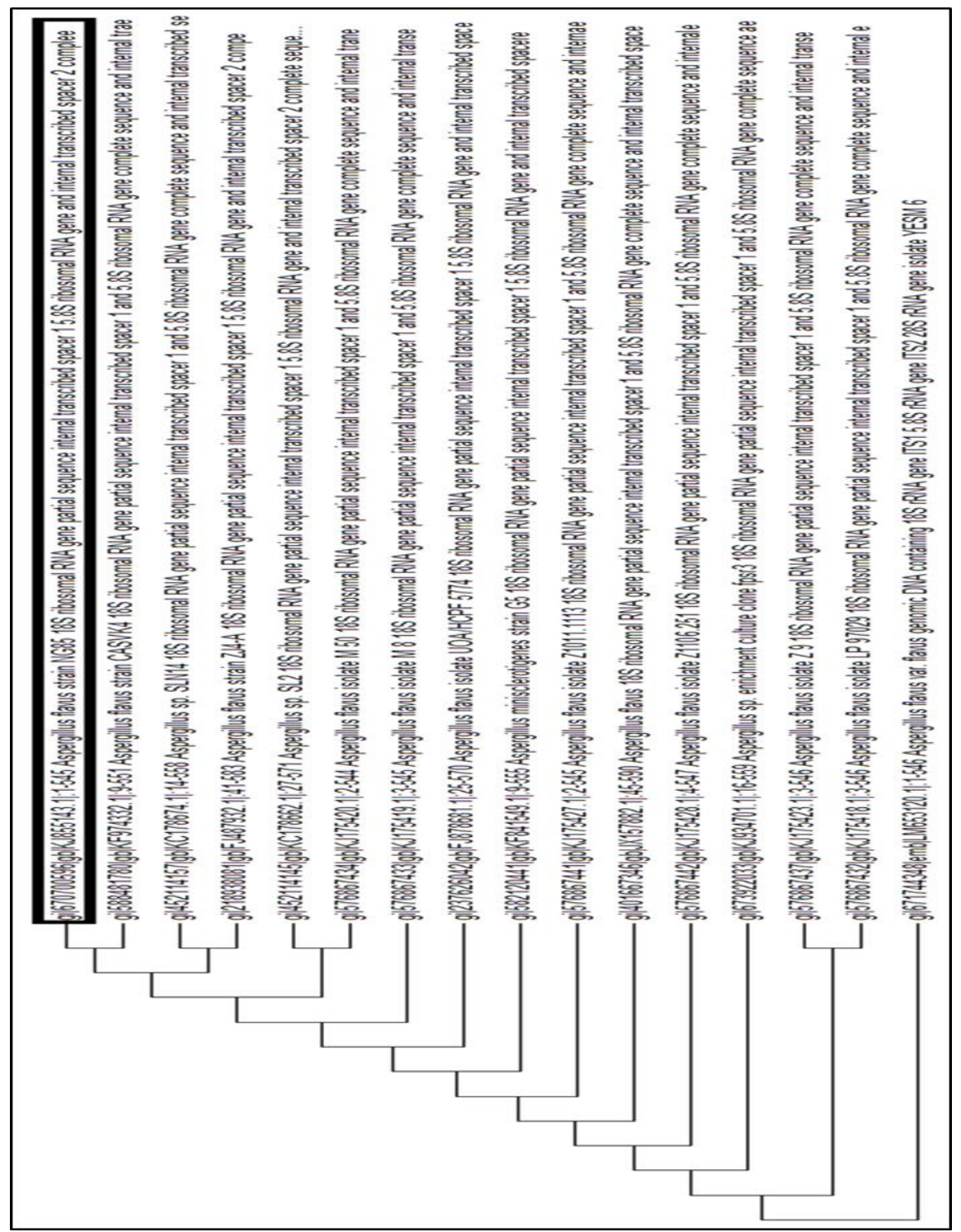

Fig. 1. Phylogenetic tree showing genetic relationship between the isolate $A$. flavus NG85 (first one from the top) and other closely related reference microorganisms. 


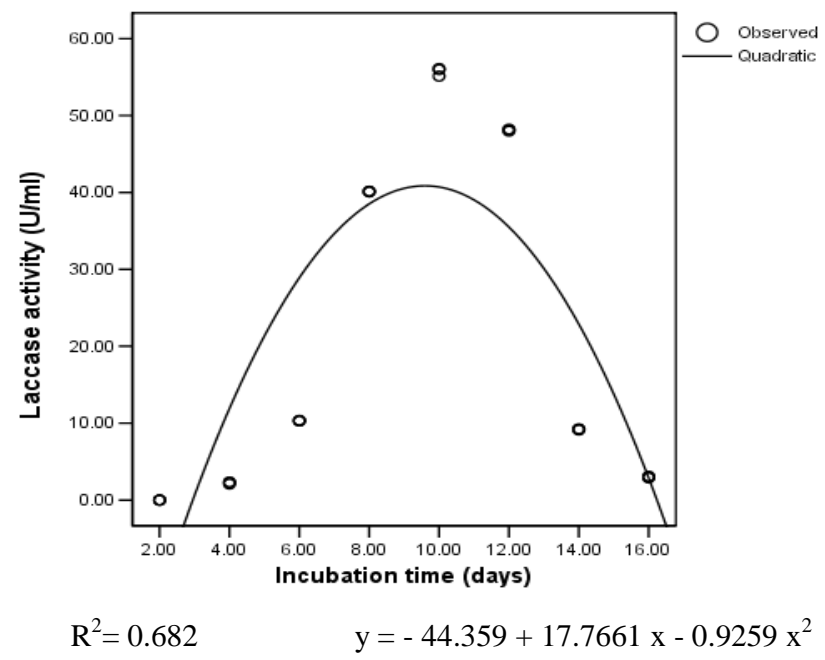

Fig. 2. Effect of incubation period on laccase production by $A$. flavus NG85 .

Incubation temperature

It appears from Fig. 3 that the gradual increase in temperature led to corresponding increase in the amount of laccase with optimum at $36.7^{\circ} \mathrm{C}$ with activity of $42.2 \mathrm{U} / \mathrm{ml}$. The increase in temperature above optimum temperature caused a decrease in enzyme activity.

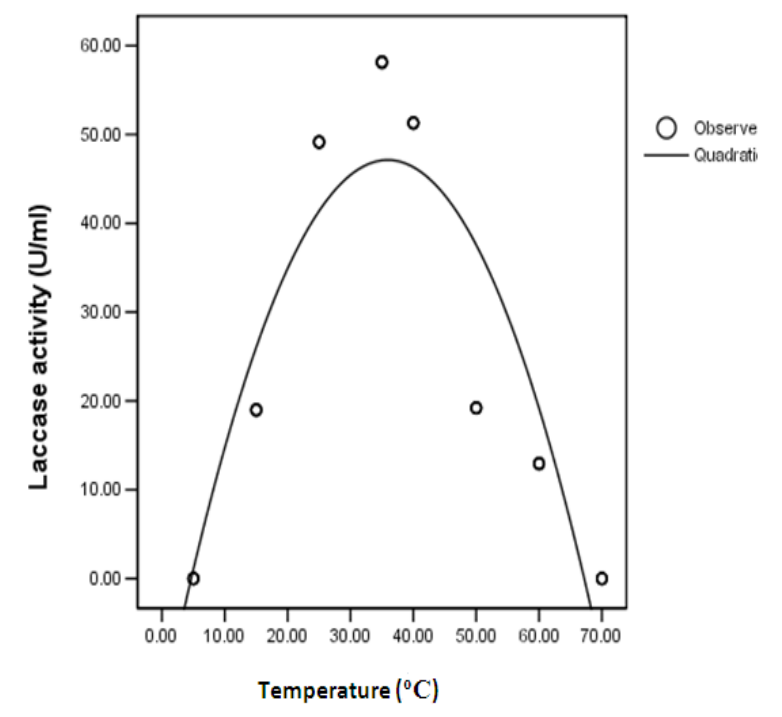

$$
\mathrm{R}^{2}=0.81386
$$$$
\mathrm{y}=-15.056+3.4627 \mathrm{x}-0.0482 \mathrm{x}^{2}
$$

Fig. 3. Effect of incubation temperature on laccase production by $A$. flavus NG85 .

Egypt. J. Bot., 55, No. 1 (2015) 
$p H$

From Fig. 4, it was found that the statistical optimum $\mathrm{pH}$ for enzyme production was 5 with activity of $46.0 \mathrm{U} / \mathrm{ml}$. Any change in this $\mathrm{pH}$ value led to a decrease in enzyme production.

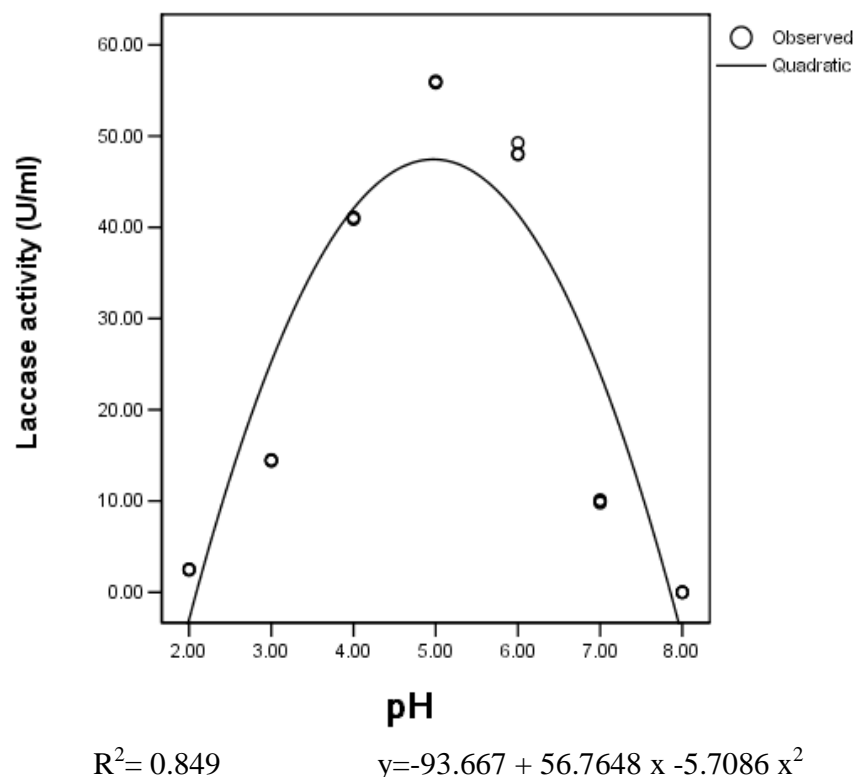

Fig. 4. Effect of different $\mathrm{pH}$ values on laccase production of $A$. flavus NG85 .

\section{Carbon sources}

Figure 5 reveals the effect of different carbon sources at concentration $2 \%$ on laccase production by $A$. flavus NG85after 10 days of growth at $36.7^{\circ} \mathrm{C}$ and $\mathrm{pH}$ 5. Sucrose was used as carbon source in control experiment, yielded 40.13 $\mathrm{U} / \mathrm{ml}$. Obviously, D-glucose induced highest laccase production $(46.83 \mathrm{U} / \mathrm{ml})$ as compared with control. Starch exhibited statistically significant increases in laccase production $(41.41 \mathrm{U} / \mathrm{ml})$. On the other hand, maltose and fructose exhibited statistically significant decreases in laccase production (38.12, 19.06 $\mathrm{U} / \mathrm{ml}$, respectively), while lactose exhibited the lowest decrease in laccase production $(10.51 \mathrm{U} / \mathrm{ml})$ compared with control.

\section{Glucose concentrations}

The increase in glucose concentration up to $24 \mathrm{~g} / \mathrm{l}$ led to a high increase in the amount of laccase enzyme (Fig. 6). Statistically, this is the optimum glucose concentration for enzyme production with $51.9 \mathrm{U} / \mathrm{ml}$ activity. Decrease in enzyme production was achieved above the optimum concentration. 


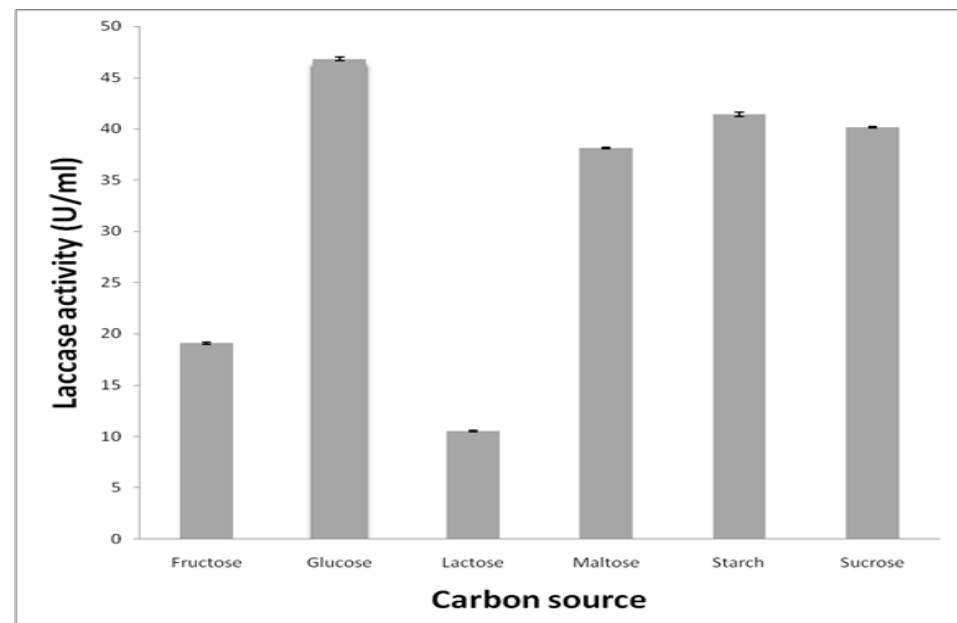

Bars show Means. Error Bars show Mean \pm SE.

Fig. 5 . Effect of different carbon sources on laccase production of $A$. flavus NG85 .

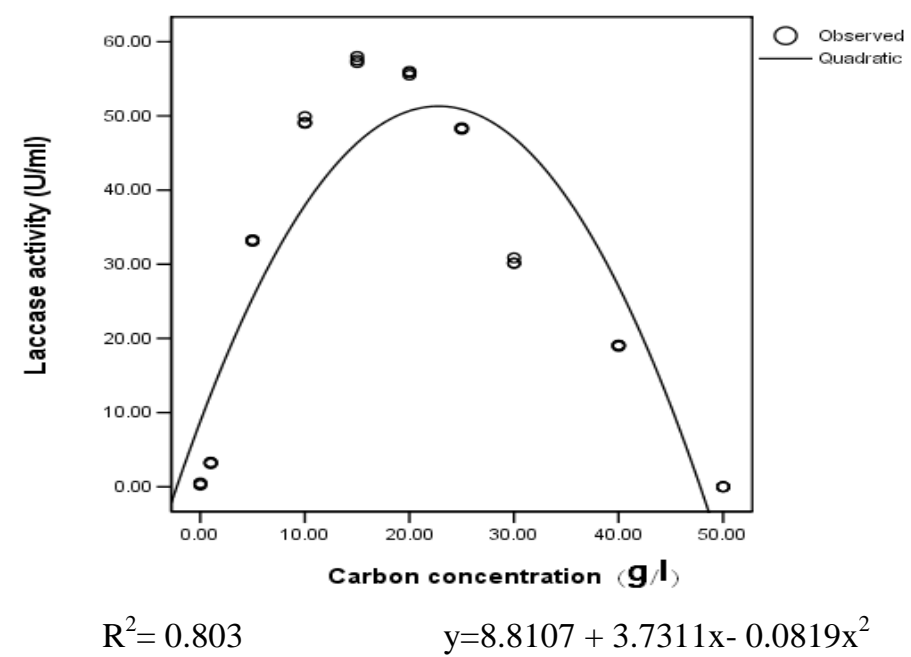

Fig. 6. Effect of different glucose concentrations on laccase production by A. flavus NG85.

\section{Nitrogen sources}

Figure 7 shows the effect of different nitrogen sources on laccase production by A.flavus NG85. Sodium nitrate was used as control. Obviously, peptone induced highest significant laccase production with activity of $53.10 \mathrm{U} / \mathrm{ml}$. Glycine exhibited statistically significant decrease in enzyme activity $(43.55 \mathrm{U} / \mathrm{ml})$. Also significant decrease in laccase production was evident when using the inorganic nitrogen sources.

Egypt. J. Bot., 55, No. 1 (2015) 


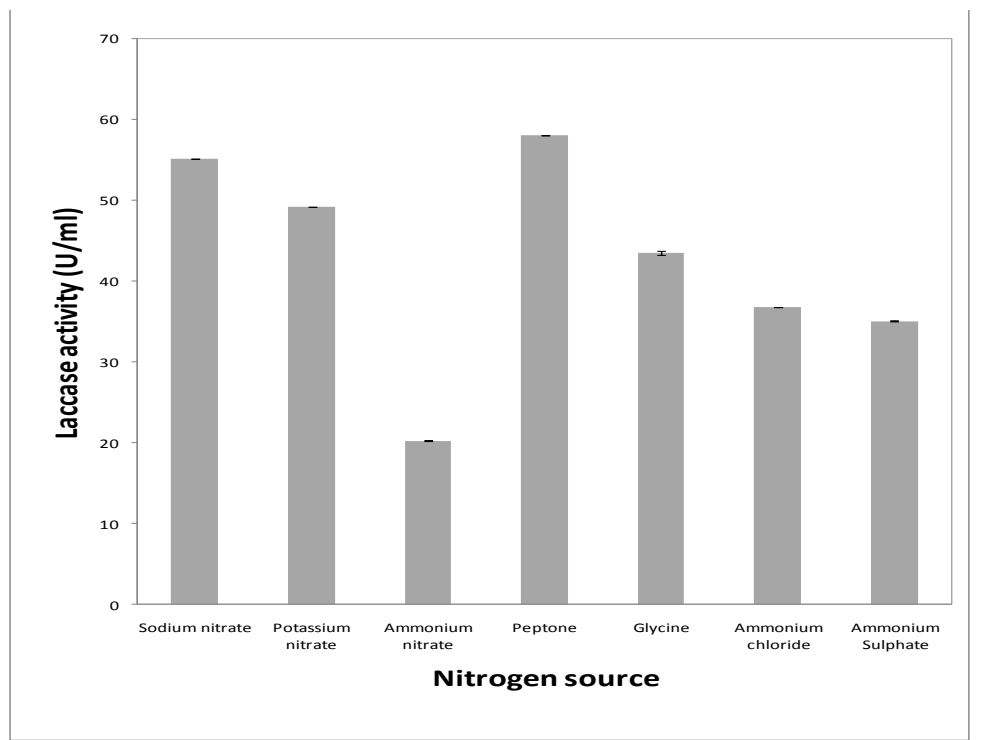

Bars show Means. Error Bars show Mean \pm SE.

Fig. 7. Effect of different Nitrogen sources on laccase production of A. flavus NG85 .

Peptone concentrations

Figure 8 reveals the effect of different peptone concentrations on laccase production by A. flavus NG85. The gradual increase in peptone concentration led to a concomitant increase in the amount of laccase enzyme with maximum activity of $53.9 \mathrm{U} / \mathrm{ml}$ at $2.51 \mathrm{~g} / \mathrm{l}$. A decrease in enzyme activity was noticed above this concentration.

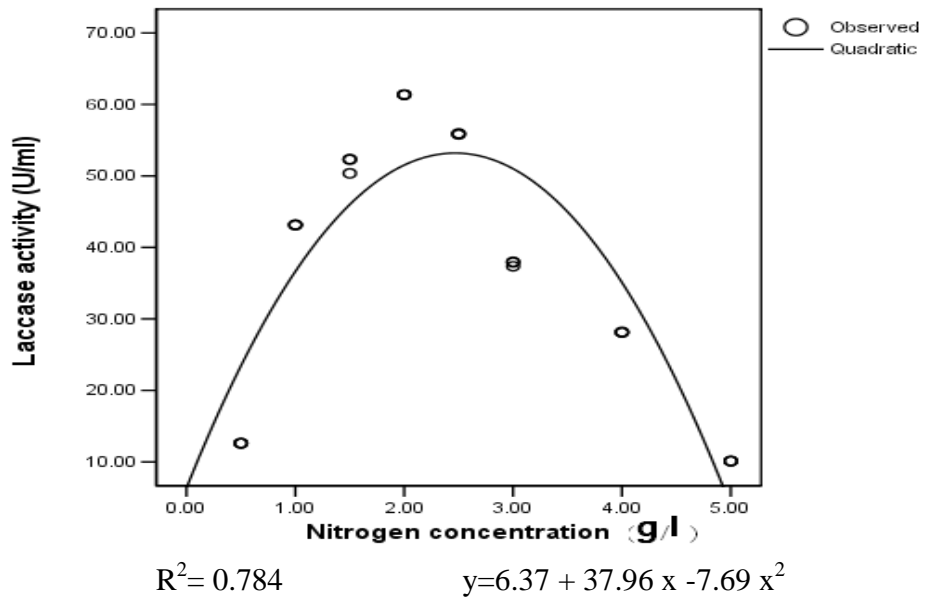

Fig. 8. Effect of different peptone concentrations on laccase production by A. flavus NG85.

Egypt. J. Bot., 55, No. 1 (2015) 


\section{Metal ions}

Figure 9 depicts the effect of different metal ions on laccase production. Among the tested compounds there was a significant inhibition in laccase induction exhibited by ferrous sulfate, magnesium sulfate, calcium chloride or sodium chloride. A statistically non-significant change was noticed for potassium chloride. An enhancement in laccase production was caused by manganese sulfate or potassium chloride. However, the highest significant promotive effect was due to copper sulfate addition with percentage increase over control (0.0 metal ion) of $122 \%$.

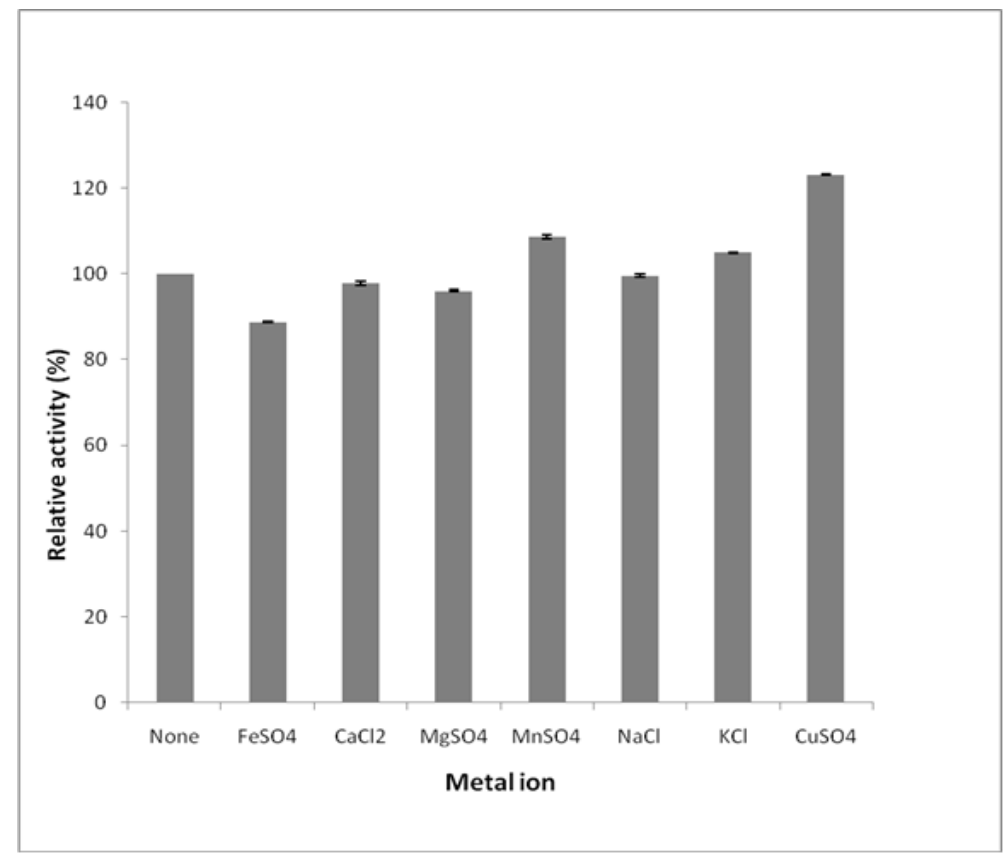

Bars show means. Error Bars show Mean \pm SE.

Fig. 9. Effect of different metal ions on laccase production by A. flavus NG85 .

Evaluation of antitumor activity of crude laccase preparation ofA. flavus NG85

The crude protein extract of A. flavus NG85 was tested against colon carcinoma cells (HCT-116 cell line), breast carcinoma cells (MCF-7 cell line) and hepatocellular carcinoma cells (HepG-2 cell line). The crude protein extract showed strong inhibitory activities toward colon carcinoma cells (Fig. 10a) and breast carcinoma cells (Fig. 10b) with IC $_{50}$ values of 24.3 and $41.3 \mu \mathrm{g} / \mathrm{ml}$, respectively. However, a weaker depressive effect was shown against hepatocellular carcinoma cells (Fig. 10c). 

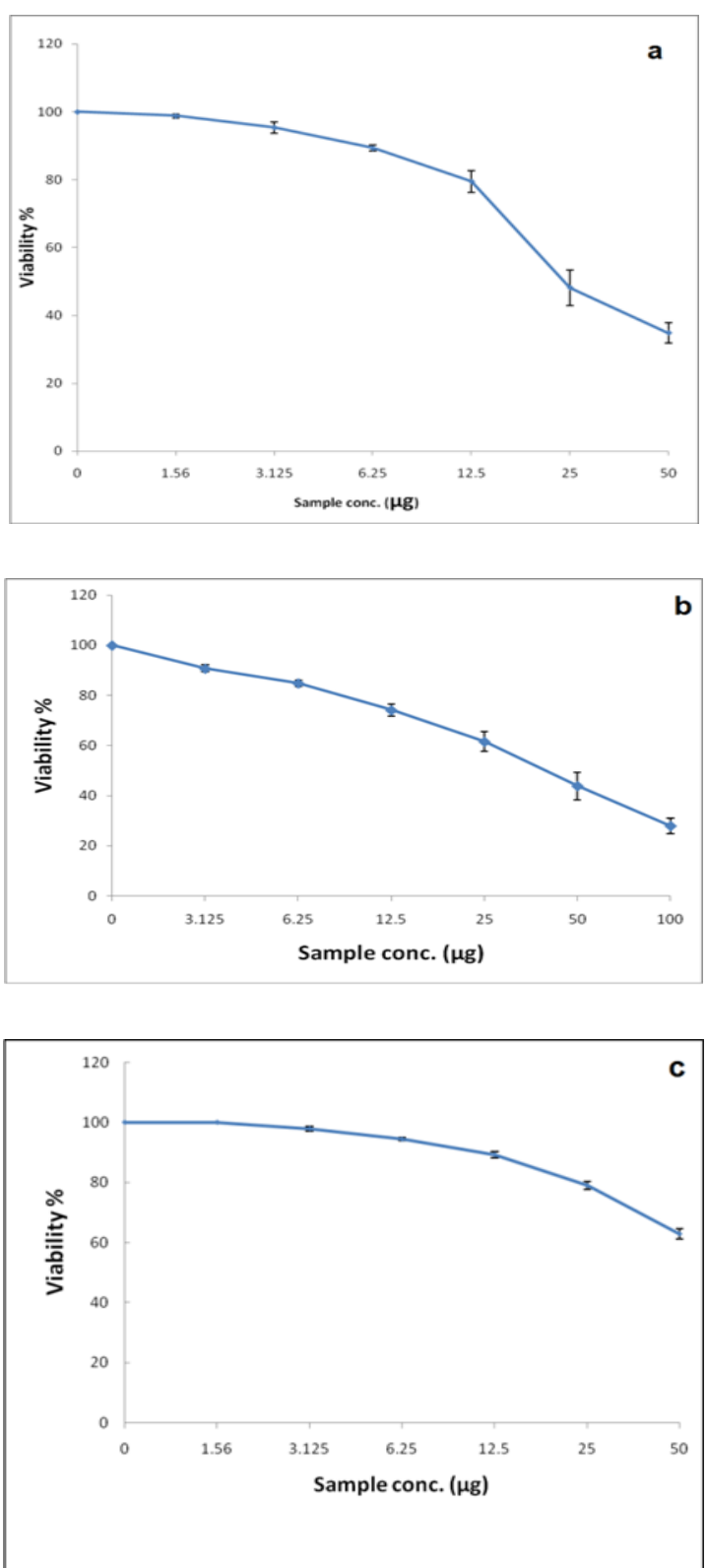

Fig. 10. Effect of crude laccase preparation of A. flavus on cell viability ratio of: aColon carcinoma cells (HCT-116 cell line), b- Breast carcinoma cells (MCF7 cell line) and c-hepatocellular carcinoma cells (HepG-2 cell line).

Egypt. J. Bot., 55, No. 1 (2015) 


\section{Discussion}

Laccase is most widely distributed in a wide range of higher plants and fungi (Benfield et al., 1964) as well as in bacteria (Diamantidis et al., 2000). Most of the laccases described in literature were isolated from higher fungi. Laccases have been isolated from ascomycetes, deuteromycetes and basidiomycetes (Assavanig et al., 1992).The present study firstly aimed to isolate fungi and bacteria from different localities. The microfloral pictures in Saint Catherine protectorate, Cairo Zoo garden and Cairo University soil were studied. Despite the fact that the Saint Catherine protectorate soil showed the least species diversity $(\mathrm{H}=0.4)$, compared with the other tested soils, Aspergillus flavus isolate obtained from this soil exhibited the highest laccase production on solid as well as on liquid media. Accordingly, this isolate was chosen to optimize its cultural conditions for maximum laccase production and activity. It was thought advisable to confirm its identification at the molecular level. The obtained 545bp-long nucleotide sequence was deposited in NCBI GenBank and was given a strain identifier, $A$. flavus NG85, with accession number: KJ855143.

It was found that maximum laccase production by A. flavus NG85 was reached after10 days of growth. Various incubation periods were achieved by different microorganisms. The white rot fungus Pycnoporus cinnabarinus produced maximum level of laccase on day 5 and accounted for about $70 \%$ of the total extracellular protein (Eggert et al., 1996). Laccase production from Cyathusbulleri was detectable after 2 days and reached maximum on day 7 (Vasdev et al., 1994). The onset oflaccase activity in Trichoderma harzianum WL1occurred on day 2 and reached its maximum on day 4 and then the rate of enzyme production declined gradually. The difference in time course of laccase production by the various fungal systems mainly dependson the source, media composition and type of inducers (Sadhasivam et al., 2008).

Pointing et al. (2000) stated that the optimum temperature range for laccase production is between 25 and $30^{\circ} \mathrm{C}$. However, A. flavus NG85 in this work showed maximum production of laccase at $36.7^{\circ} \mathrm{C}$.

Maximum production of laccase by A. flavus NG85 occurred in the acidic $\mathrm{pH}$ (5). Earlier reports suggested that $\mathrm{pH}$ between 4.5 and 6.0 is suitable for laccase production (Thurston, 1994).

Laccase production by fungi has been found to be largely affected by nutritional conditions, such as carbon and nitrogen source and related concentrations and microelements. Laccases are generally produced in low concentrations by fungi, but higher concentrations could be obtained by adding various supplements to liquid growth media (Lee et al., 1999 and Vasconcelos et al., 2000).

In this work, the monosaccharide D-glucose was the most potent carbon source inducing maximum laccase production at an optimum concentration of $24 \mathrm{~g} / \mathrm{l}$.This is in accordance with Leifa et al. (2007) who reported that utilization

Egypt. J. Bot., 55, No. 1 (2015) 
of monosaccharides for laccase production is better compared to sugar alcohol and complex sugar due to their simple nature.

A. flavus NG85 in this study achieved highest laccase production when using peptone as a nitrogen source with optimum concentration of $2.51 \mathrm{~g} / \mathrm{l}$. It was proven that nitrogen sources and their concentrations were as important nutritional factors as carbon sources in regulating laccase production (Minussi et al., 2002). Vahidi et al. (2004) reported that when yeast extract was used as nitrogen source it increased laccase production. A decrease in enzyme production was seen when inorganic nitrogen sources were used alone in the growthmedium. Oppositely, Elisashvili et al. (2001) reported high laccase production in $C$. unicolor IBB 62, grown in a medium with ammonium sulfate as the only nitrogen source.

The data reached in this study showed that supplementation of copper sulfate at a concentration of $10 \mu \mathrm{M}$ caused significant enhancement in laccase production. These findings are in agreement with previous reports showing that the addition of $2 \mathrm{mM} \mathrm{CuSO} 4$ during the exponential growth phase of fungal growth led to a remarkably increased laccas eproduction (Galhaup et al., 2002; Couto and Sanroman, 2005).Almost a similar effect was observed in the cultures of Trametes multicolor MB 49 and Trametes trogii BAFC 463 with copper concentrations ranging from 0.5 to $2.0 \mathrm{mM}$. Sadhasivam et al. (2008) found that copper sulfate supplementation at $1 \mathrm{mM}$ concentration yielded high amounts of laccase. The formation of laccase by a Bacillus sp. was considerably increased by addition of $1 \mathrm{mM}$ copper sulfate (Kaushikand Thakur, 2014). Addition of inducers enhanced the production of laccase at the level of gene transcription. The promoter regions of the genes encoding for laccase contain various recognition sites that are specific for xenobiotics and heavy metals. It has been demonstrated that the Pleurotuso streatus laccase genes poxc and poxalb are transcriptionally induced by copper, and several putative metal responsive elements (MREs) were found in the promoter regions of thes egenes (Faraco et al., 2003).

Urgent need for novel anticancer drugs has paved way for the usage of fungi and their products withanti-cancer properties. In this work, the crude enzyme preparation produced by A. flavus NG85 showed high cytotoxic activities against colon carcinoma cells or breast carcinoma cells and a less inhibitory effect against hepatocellular carcinoma cells was detected. This effect could be due to laccase and/or other proteins produced by A. flavus NG85, since the cultivation medium was oriented to high laccase production. However, it is recommended for future work to purify and characterize laccase produced by A.flavus NG85. Hu et al. (2011) purified alaccase from fresh fruiting bodies of the edible white common Agrocybe cylindracea mushroom. It caused HIV-1 reverse transcriptase inhibitory activity $\left(\mathrm{IC}_{50}=12.7 \mu \mathrm{M}\right)$ and antiproliferative activity against HepG2 cells $\left(\mathrm{IC}_{50}=5.6 \mu \mathrm{M}\right)$ and MCF7 cells $\left(\mathrm{IC}_{50}=6.5 \mu \mathrm{M}\right)$.

Egypt. J. Bot., 55, No. 1 (2015) 
In conclusion, A. flavus NG85 strain isolated from Saint Catherine protectorate achieved highest amounts of extracellular laccase. Its growth medium was directed toward maximum biosynthesis of the enzyme. The crude enzyme extract of the fungal filtrate proved high antitumor potency against colon carcinoma cells and breast carcinoma cells and a less cell toxicity against hepatocellular carcinoma cells.

\section{References}

Aisemberg, G.O., Grorewold E.,Taccioli, G.E. and Judewicz, N. (1989) A major transcript in the response of Neurospora crassa to protein synthesis inhibition by cycloheximide.Exp. Mycol., 13: $121-128$.

Assavanig, A., Amornkitticharoen, B., Ekpaisal, N., Meevootisom,V. and Flegel, T. W. (1992) Isolation, characterization andfunction of laccase from Trichoderma. Appl.Microbiol. Biotechnol., 38: 198-202.

Benfield, G., Bocks, S.M., Bromley, K. and Brown, B.R. (1964) Studies in fungal and plant laccases.Phytochem., 3: $79-88$

Couto, S.R. and Herrera, J.L.T. (2006) Industrial and biotechnological applications of laccases: A review. Biotechnol. Advances, 24: 500 - 513.

Couto, S.R. and Sanroman, M.A. (2005) Coconut flesh: A novel raw material forlaccase production by Trametes hirsuta under solid state conditions. application to lissamine green B decolorization. J. Food Eng., 71: 208-13.

Das, P., Mukherjee, S. and Sen, R. (2008) Improved bioavailability and biodegradation of a model polyaromatic hydrocarbon by a biosurfactant producing bacterium of marine origin.Chemosphere,72: 1229-1234.

Diamantidis, G., Effosse, A., Potier, P. and Bally, R. (2000) Purification and characterization of the first bacterial laccase in the rhizospheric bacterium Azospirillum lipoferum. Soil Biol. Biochem., 32: 919-927.

Duran, N. and Esposito, E. (2000) Potential applications of oxidative enzymes and phenoloxidase-like compounds in wastewater and soil treatment: A review: Appl.Catal. B Environ., 28: 83-99.

Eggert, C., Temp, U. and Eriksson, K.E.L. (1996) The ligninolytic system of the white rot fungus Pycnoporus cinnabarinus: purification and characterization of the laccase. Appl. Environ.Microbiol., 62: 1151-8.

Elisashvili, V., Parfar, H., Kachlishvili, E., Chichua, D., Bakradze, M. and Kokhreidze, N. (2001) Ligninolytic activity of basidiomycetes grown under submerged and solid-state fermentation on plant raw material (sawdust of grapevine cuttings). Adv. in Food Sci.,23: 117-123.

Faraco, V., Giardina, P. and Sannia, G. (2003) Metal-responsive elements in Pleurotus ostreatus laccase gene promoters. Microbiol., 149: 2155-62.

Egypt. J. Bot., 55, No. 1 (2015) 
Galhaup, C., Wagner, H., Hinterstoisser, B. and Haltrich, D. (2002) Increased production of laccase by the wood-degrading basidiomycete Trametes pubescens. Enzyme Microb. Technol., 30: 529-36.

Giardina, P., Faraco, V., Pezzella, C., Piscitelli, A., Vanhulle, S. and Sannia, G. (2010)Laccases: A never-ending story.Cell Mol. Life Sci.,67: 369 - 385.

Gilman, J. C. (1957) "A MAnual of Soil Fungi". The Iowa State College Press, Ames, Iowa, U.S.A., pp. 450.

Heap, L., Green, A., Brown, D., van Dongen, B. and Turner, N. (2014) Role of laccase as an enzymatic pretreatment method to improve lignocellulosic saccharification. Catal. Sci. Technol., 4: 2251-2259.

Hu, D.D., Zhang, R.Y., Zhang, G.Q., Wang, H.X. and Ng, T.B. (2011) A laccase with antiproliferative activity against tumor cells from an edible mushroom, white common Agrocybe cylindracea. Phytomed., 18: 374-9.

Johnson, L. F.,Curi, E. A., Bond, J. H. and Fribourg, H. A. (1960) "Methods for Studying Soil Microflora-Plant Disease Relationship". Burgess Publishing, Minneapolis, U.S.A., pp. 178.

Kaushik, G. and Thakur, I.S. (2014) Production of laccase and optimization of its production by Bacillus sp. using distillery spent wash as inducer. Bioremed. J., 18: 28-37.

Kiiskinen, L. and Saloheimo, M. (2004) Molecular cloning and expression in Saccharomyces cerevisiae of a laccase gene from the ascomycete melanocarpus albomyces. Appl. Environ. Microbiol.,70: 137-144.

Lee, I.Y., Jung, K.H., Lee, C.H. and Park, Y.H. (1999) Enhanced production of laccase in Trametes versicolor by the addition of ethanol. Biotechnol. Lett., 21: 965-8.

Leifa, F., Andra, T.S., Ashok, P. and Carlos, R.S. (2007) Effect of nutritional and environmental conditions on production of exopolysaccharide of Agaricus brasiliensis by sub-merged fermentation and its antitumor activity. LWT J., 40: $30-35$.

Levine, W. (1965) "The Biochemistry of Copper", Academic Press Inc., New York,p. 371-385.

Martins, L., Soares, C., Pereria, M., Teixeira, M., Costa, T., Jones, G. and Henriques, A. (2002) Molecular and biochemical characterization of a highly stable 28 bacterial laccase that occurs as a structural component of the Bacillus subtilis endospore coat. J. Biol. Chem., 277: 18849-18859.

Mayer, A. and Staples, R. (2002) Laccase : New functions for an old enzyme: Phytochem., 60: 551-65.

Minussi, R.C., Pastore, G.M. and Duran, N. (2002) Potential applications of laccase in the food industry. Trends in Food Sci. Technol., 13: 205-216.

Egypt. J. Bot., 55, No. 1 (2015) 
Mosmann, T. (1983) Rapid colorimetric assay for cellular growth and survival: Application to proliferation and cytotoxicity assay. J. Immunol. Methods, 65: 55-63.

Moubasher, A. H. (1993) "Soil Fungi in Qatar and Other Arab Countries". Scientific and Applied Research Center, University of Qatar, pp. 566.

Olga, V.K.S., Elena, V.S., Valeria, P.G., Olga, V.M., Natalia, V.L., Aida, N.D., Alexander, J.J. and Alexander, M. (1998) Purification and characterization of the constitutive form of laccase from basidiomycete Coriolushirsutus and effect of inducers on laccase synthesis. Biotechnol. Appl. Biochem., 28: 47-54.

Palmeri, G., Bianco, C., Cennamo, G., Giardina, P., Marino, G., Monti, M. and Sannia, G. (2001) Purification, characterization, and functional role of a novel extracellular protease from Pleurotus ostreatus. Appl. Environ.Microbiol., 67: 2754 - 2759.

Pielou, E.C. (1966) The measurement of diversity in different types of biological collection. J. Theor. Biol., 13: 131-144.

Pointing, S.B., Jones, E.B.G. and Vrijmoed, L.L.P. (2000) Optimization of laccase production by Pycnoporussanguineus in submerged liquid culture. Mycologia, 92: 139144.

Raper, K.B. and Fennell, D.L.(1965) "The Genus Aspergillus". Williams, Baltimore, U.S.A., pp. 876.

Sadhasivam, S., Savitha, S., Swaminathan, K. and Lin, F.H, (2008) Production, purification and characterization of mid-redox potential laccase from a newly isolated Trichoderma harzianum WL1. Process Biochem.,43: 736 - 742.

Thurston C. (1994)The structure and function of fungal laccases. Microbiol., 140: 19-26.

Vahidi, H., Kobarfard, F. and Namjoyan, F. (2004) Effect of cultivation conditions on growth and antifungal activity of Mycena leptocephala. Afr. J. Biotechnol., 3: 606-609.

Vasconcelos, A.F., Barbosa, A.M., Dekker, R.F.H., Scarminio, I.S. and Rezende, M.I. (2000) Optimization of laccase production by Botryospaeria sp. in the presence of veratryl alcohol by the response-surface method. Process Biochem., 35: 1131-8.

Vasdev, K. and Kuhad, R.C. (1994) Induction of laccase production in Cyathus bulleri under shaking and static culture conditions. Folia Microbiol., 39: 326-30.

Watanabe, T. (2002) Pictorial Atlas of Soil and Seed Fungi. "Morphologies of Cultured and Key to Species", $2^{\text {nd }}$ ed, CRC Press, Boca Raton London New York Washington D.C.

Wilson, A. P. (2000) "Cytotoxicity and Viability Assays in Animal Cell Culture: A Practical Approach", $3^{\text {rd }}$ ed. (Ed. Masters, J.R. W.), Oxford University Press.

(Received 17/9/2014; accepted $11 / 11 / 2014$ 


\title{
التخليق الحيوى لانزيم اللاكيز المنتج بواسطة اسبرجيللس فلافس

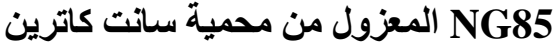

\author{
محمد ابراهيم احمد على ، سلامة ابو اليزيد عوف، نيفين محمود محمد محمد خليل

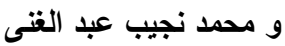 \\ قسم النبات و الميكروبيولوجى - كلية العلوم - جامعة القاهرة - الجيزة - مصر.
}

\begin{abstract}
تم دراسة صورة الفلورة الميكروبية لتربة محمية سانت كاترين و حديقة

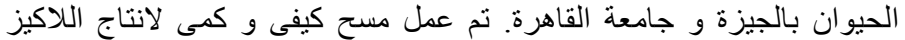

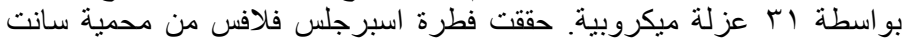

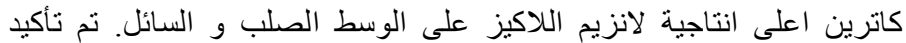

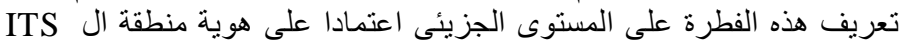

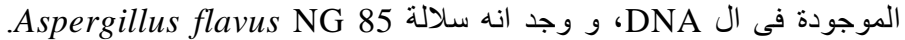

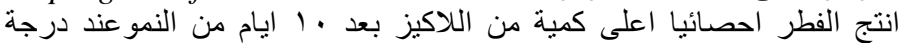

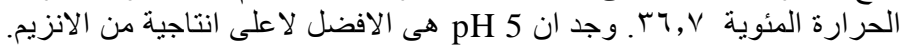

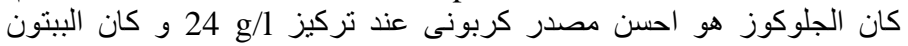

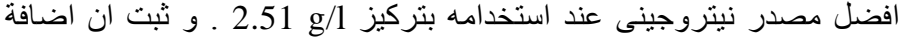

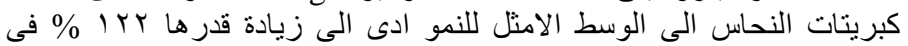

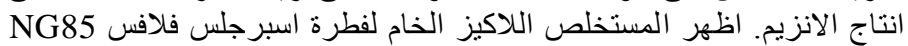

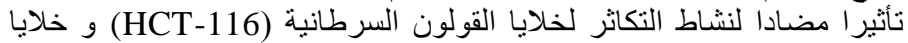
الثدى السرطانية (MCF-7) بقيم
\end{abstract} و اظهر نشاط تنثيطى اقل لخلايا الكبد السرطانية (HepG-2). 